\section{Gordana Kastratović}

Assosiate Professor University of Belgrade Faculty of Transport and Traffic Engineering

\section{Nenad Vidanović}

Assistant Professo University of Belgrade Faculty of Transport and Traffic Engineering

\section{Aleksandar Grbović}

Assosiate Professor University of Belgrade Faculty of Mechanical Engineering

Boško Rašuo

Full Professor University of Belgrade Faculty of Mechanical Engineering

\title{
Approximate Determination of Stress Intensity Factor for Multiple Surface Cracks
}

In this paper a versatile and easy to use approximate procedure was used for the estimation of mode I stress intensity factors in case of multiple surface cracks in a three dimensional elastic body, subjected to remote uniaxial tensile loading. The mentioned method uses known solutions for either $2 D$ or $3 D$ configurations containing only one crack, and takes into consideration the interaction effect between cracks. This procedure, which is based on the principle of superposition, was applied on a configuration with three coplanar semi-elliptical cracks embedded in three dimensional elastic body, subjected to remote uniaxial tensile loading. All cracks are located in the same plane at the same distances, in the middle of the body and the applied stress is perpendicular to the cracks plane. For the verification purposes, the stress intensity factors solutions were obtained by using finite element method based computer program. The conducted analysis showed that approximate method is, above all, fast and efficient tool for stress intensity factors assessment even in the case of $3 D$ configurations with multiple site damage. The comparison between results also showed the significance of accurate calculation of stress intensity factors, in order to provide a better understanding and prediction of $3 D$ multiple cracks propagation.

Keywords: Stress intensity factor, Approximate method, Semi-elliptical cracks, Multiple site damage

\section{INTRODUCTION}

Three dimensional cracks such as a surface or embedded cracks represent the most common defects in all kinds of engineering structures. The analyses of 3D cracks are necessary for retaining structural integrity of the structural element during its service life. The stress intensity factor (SIF) is the basic parameter used in fracture mechanics for stress field determination in the crack tip region. The knowledge of this crucial parameter enables the prediction of crack growth rate and residual strength of damaged structure. So, many different methods have been developed for SIFs determination. However, even that for many three dimensional planar cracks problems analytical solutions for SIFs can be found in the literature, whose list of references is given in a review paper [1], in most of these cases there is only one crack involved.

As far as multiple 3D cracks problems are concerned, those solutions are much less available. The solutions for these configurations imply the usage of various numerical methods [2-7], like extended element method (XFEM), which is nowadays becoming more prevalent since it suppresses the need to mesh and remesh the crack surfaces and is used for modelling different disconti-

Received: March 2017, Accepted: August 2017

Correspondence to: Dr Gordana Kastratović

Faculty of Transport and Traffic Engineering,

Vojvode Stepe 305, 11000 Belgrade, Serbia

E-mail: g.kastratovic@sf.bg.ac.rs

doi:10.5937/fmet1801039K

(C) Faculty of Mechanical Engineering, Belgrade. All rights reserved nuities in 1D, 2D and 3D domains [8]. All those methods are time-consuming and computationally intense $[9,10]$. Also, the mutual influence of the adjacent cracks additionally increases the complexity of this kind of analyses.

On the other hand, there is a lack of approximate methods and procedures, which can provide faster and simpler determination of stress intensity factors of 3D configurations with multiple cracks. One of the rare methods of this kind is a simple method of stress analysis in elastic solids with many cracks [3].

In this paper, a versatile and easy to use approximate procedure was used for the estimation of mode I stress intensity factors in case of multiple surface cracks in a three dimensional elastic body, subjected to remote uniaxial tensile loading. The mentioned method uses known solutions for either 2D or 3D configurations containing only one crack, and takes into consideration the interaction effect between cracks. This effect has been determined approximately and presented through interaction effect coefficients, which take into consideration the increase of stress intensity factor of analyzed crack due to interaction with existing adjacent crack. The accuracy of calculated SIFs was verified by comparison with the solutions obtained by finite element method (FEM) based computer program.

\section{SIF ASSESSMENT IN A CASE OF MULTIPLE CRACKS}

The approximate procedure for calculating stress intensity factors was developed in $[11,12]$. This pro- 
cedure is based on principle of superposition. According to this procedure the SIFs in case of three coplanar semi-elliptical cracks embedded in a three dimensional elastic body subjected to remote uniaxial tensile loading (Figure 1) can be estimated as:

$$
K_{I 1 B}=c_{1 b, d} \cdot K_{I 1}+c_{2 b, d} \cdot K_{I 2}+c_{3 b, d} \cdot K_{I 3}
$$

where:

$K_{I I} \quad$ - strass intensity factor of the first crack;

$K_{I 2} \quad$ - strass intensity factor of the second crack;

$K_{I 3} \quad$ - strass intensity factor of the thrid crack;

$c_{i b, d} \quad$ - the coefficient that takes into consideration influence of i-th crack on the stress intensity factor of the analyzed crack, (the influential coefficient of the analyzed crack on itself is $\left.c_{j b, d}\right),(i=1, \ldots 3)$.

Because of the symmetry of the analyzed configuration $\left(K_{I 2}=K_{I 3}\right.$ and $\left.a_{2}=a_{3}\right)$, and if the previous equation is written as a function of geometry factors, i.e. normalized stress intensity factor $\left(\beta_{i}=\frac{K_{I i}}{\sigma \sqrt{\pi \cdot a_{i}}}\right)$, and then divided by $\sigma \sqrt{a_{1} \pi}$, the following equation is obtained:

$$
\beta_{1 B}=c_{1 b} \beta_{1}+\left(c_{2 b}+c_{3 d}\right) \cdot \beta_{2} \sqrt{\frac{a_{2}}{a_{1}}}
$$

where $c_{l b, d}=1$.

In this case all three auxilliary configurations are the same (surface crack in a plate). The geometry factors $\beta_{1}$ and $\beta_{2}=\beta_{3}\left(a_{2}=a_{3}\right)$ for them are determined as in [13].

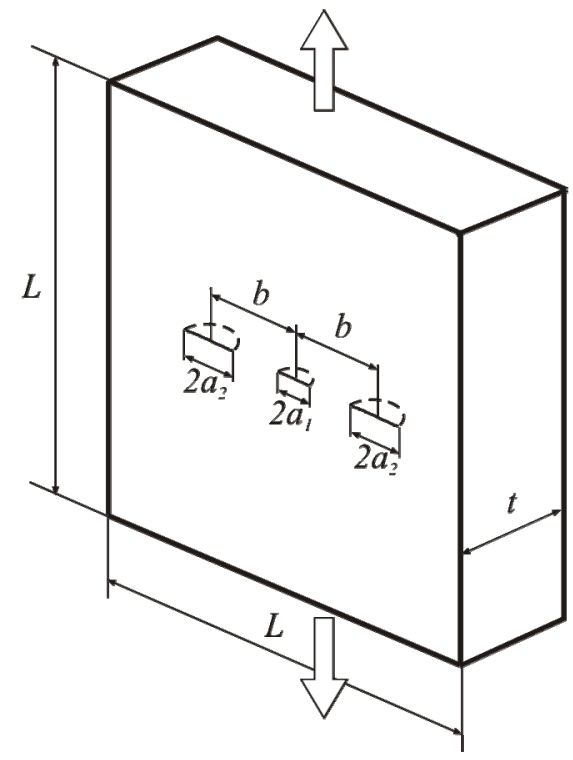

a)

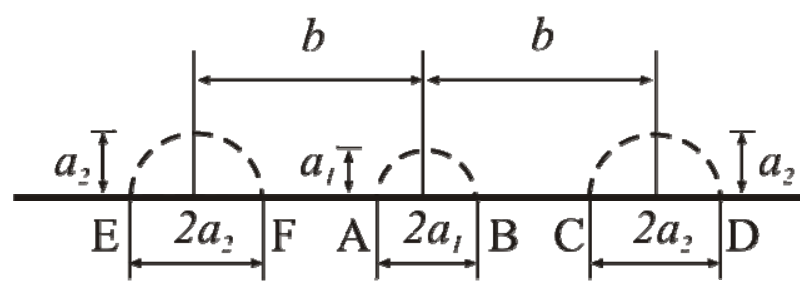

b)

Figure 1. Three semi-elliptical cracks, their size and position and crack tips denotations
The same procedure is applied for calculating geometry factors for all other crack tips, where, because of the symmetry $\beta_{\mathrm{A}}=\beta_{\mathrm{B}}, \beta_{\mathrm{F}}=\beta_{\mathrm{C}}, \beta_{\mathrm{E}}=\beta_{\mathrm{D}}$ :

$$
\begin{aligned}
& \beta_{F}=\beta_{1} c_{1 b} \sqrt{\frac{a_{1}}{a_{2}}}+\beta_{2}+\beta_{2} c_{3 b} \\
& \beta_{E}=\beta_{1}+\beta_{2} c_{2 d}+\beta_{2} c_{1 d} \sqrt{\frac{a_{1}}{a_{2}}}
\end{aligned}
$$

The influential coefficients in equations (2), (3) and (4) were estimated by the application of presented method to the configuration with two unequal cracks in an infinite plate subjected to remote uniform stress, as shown in [1]. As previously mentioned, the geometry factors, i.e. the SIFs, were estimated for three coplanar semi-elliptical cracks embedded in a three dimensional elastic body, subjected to remote uniaxial tensile loading. The side cracks are of the same size, while the central crack has a different size, with equal major and minor axes (Figure 1b). All cracks are located in the same plane at the same distances, in the middle of the body and the applied stress is perpendicular to the cracks plane. Material of the plate is aluminum alloy Al2024 T3.

Further, the stress intensity factors solutions were obtained and verified by using FEM. Those calculations were carried out in ANSYS Workbench.

The cracks inside ANSYS Mechanical are defined as a semi-elliptical crack objects. The computer program uses the geometric parameters to define the semi-elliptical crack shape and crack front in three dimensional analysis. These geometric inputs along with additional inputs parameters define the region and shape of the generated crack mesh. Internally, the crack mesh generation is performed after the creation of the base mesh.

The FE model was created parametrically, so that SIFs solution could be calculated automatically for different sizes of all cracks.

In this case of the mode 1 , SIF is computed along the crack front using the interaction integral method. The interaction integral method for the SIF calculation applies volume integration for 3D problems and area integration for $2 \mathrm{D}$ problems. The interaction integral [14] is defined as:

$$
I=\frac{-\int_{V} q_{i, j}\left(\sigma_{k l} \varepsilon_{k l}^{a u x} \delta_{i j}-\sigma_{k j}^{a u x} u_{k i}-\sigma_{k j} u_{k i}^{a u x}\right) d V}{\int_{s} \delta q_{n} d s}
$$

where $\sigma_{i j}, \varepsilon_{i j}, u_{i}$ are the stress, strain and displacement, $\sigma_{i j}^{a u x}, \varepsilon_{i j}^{a u x}, u_{i}^{a u x}$ are the stress, strain and displacement of the auxiliary field, and $q_{i}$ is the crack-extension vector.

The interaction integral is associated with the stressintensity factors as:

$$
I=\frac{2}{E^{*}}\left(K_{1} K_{1}^{a u x}+K_{2} K_{2}^{a u x}\right)+\frac{1}{\mu} K_{3} K_{3}^{a u x}
$$


where $K_{i}(\mathrm{i}=1,2,3)$ are mode $I, I I$, and III SIFs, $K_{i}^{\text {aux }}(i=1,2,3)$ are auxiliary mode $I, I I$, and III SIFs, $E^{*}=E$ for plane stress and $E^{*}=\frac{E}{1-v^{2}}$ for plane strain, $E$ is Young's modulus, $v$ is Poisson's ratio and $\mu$ is shear modulus.

The computer program calculates the SIFs via interaction integral evaluation at the solution phase of the analysis, and then stores the values to the results file.

The FEM models for $b=10[\mathrm{~mm}]$ are given in Figures 2-4 for three characteristic crack sizes: for initial crack size $a_{1}=a_{2}=a_{3}=1 \quad[\mathrm{~mm}]$, where the influences of adjacent cracks interaction are minimal, then for the same and the maximum sizes of both cracks $a_{1}=a_{2}=a_{3}=4[\mathrm{~mm}]$, when the minimal distance between crack fronts is $2[\mathrm{~mm}]$ and where the influences of adjacent cracks interaction are maximal, and finally in the case $a_{1}=8[\mathrm{~mm}]$, and $a_{2}=a_{3}=0.7[\mathrm{~mm}]$, when one crack is significantly larger than the other one and when the minimal distance between crack fronts is $1.3[\mathrm{~mm}]$ and where the influences of adjacent cracks interaction are also very prominent.

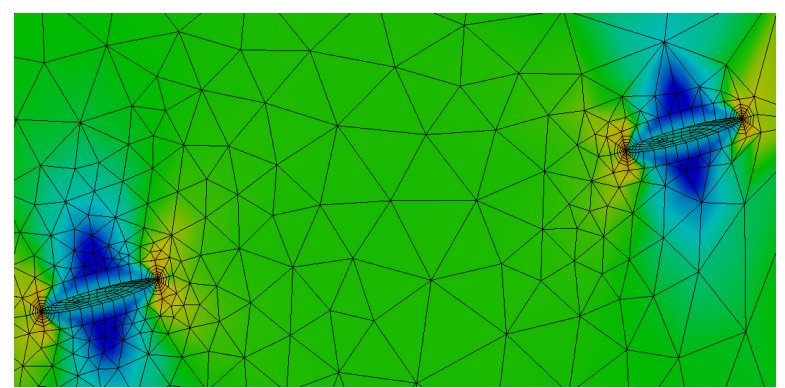

Figure 2. FEM model for $b=10[\mathrm{~mm}]$ and $a_{1}=a_{2}=a_{3}=1[\mathrm{~mm}]$

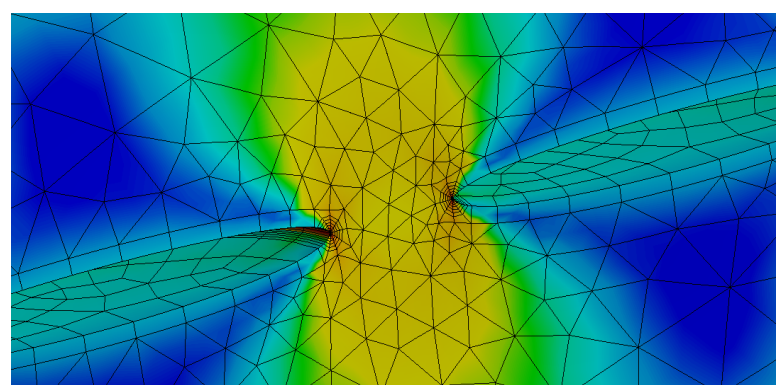

Figure 3. FEM model for $b=10[\mathrm{~mm}]$ and $a_{1}=a_{2}=a_{3}=4[\mathrm{~mm}]$

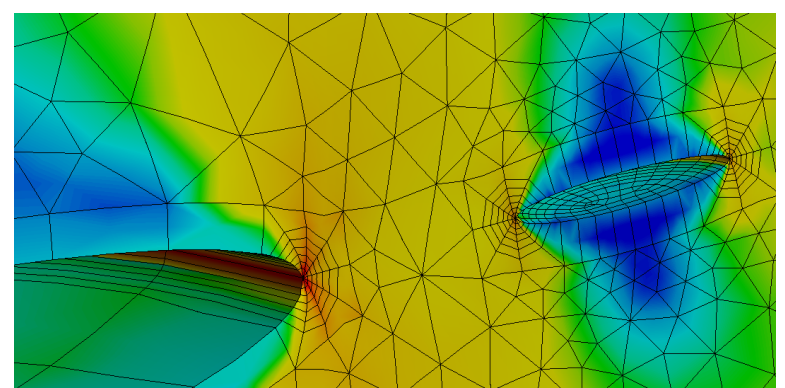

Figure 4. FEM model for $b=10[\mathrm{~mm}]$ and $a_{1}=8[\mathrm{~mm}]$ and $a_{2}=a_{3}=0.7[\mathrm{~mm}]$

\section{DISCUSSION OF THE RESULTS}

The SIFs are calculated for models with different crack sizes for both cracks in the configuration, and two different distances.
The results are presented through normalized stress intensity factors (geometry factors $\beta$ ) for both cracks in analyzed configuration denoted as in Figure $1 \mathrm{~b}$. The length of the crack 1 is marked as $a_{l}$, and the length of the crack 2 and crack 3 is marked as $a_{2}$. Distance between the centers of the cracks is marked as $b$. The results are shown in the following diagrams (Figures 5 to 10$)$.

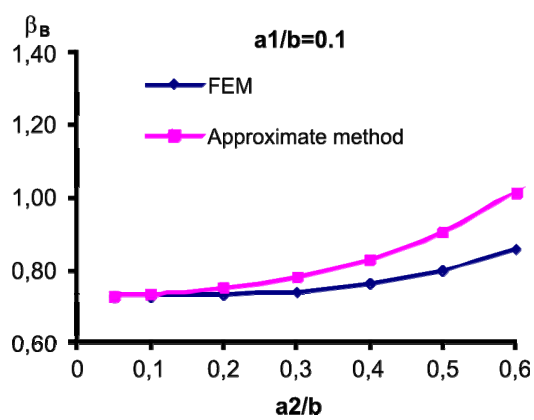

a)

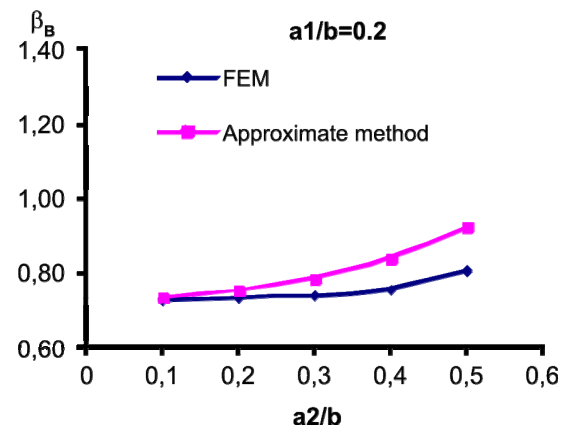

b)

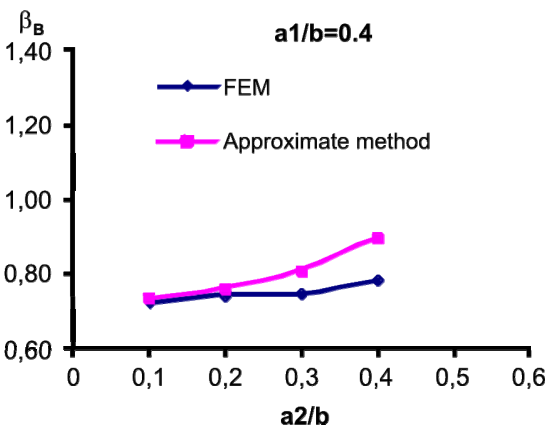

c)

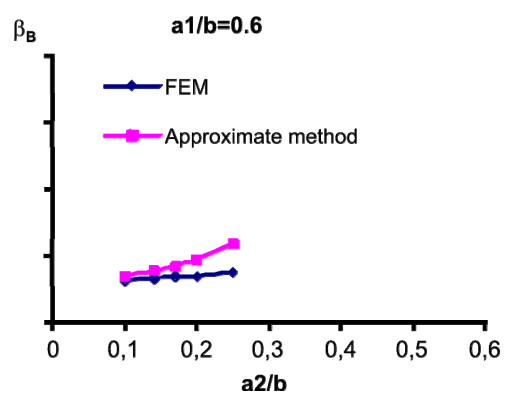

d)

Figure 5. Normalized SIFs for crack tips $A$ and $B, b=10 \mathrm{~mm}$

In the case when the $b=10[\mathrm{~mm}]$ (Figures 5 to 7 ), the maximum relative error is around $25 \%$ (third diagram in Figure 6), in the case of the same and also the maximum sizes of both cracks (Figure 4). In this case the crack tips of adjacent cracks are very close, and the increase in SIFs values is expected, because of their 
interaction. This discrepancy of the results can be explained by the fact that finite element mesh was not fine enough and also that the interaction effect coefficients used in approximate method are determined based on $2 \mathrm{D}$ model. In other cases, the relative error mainly goes up to $12 \%$, but in most cases it is well under $10 \%$. The best agreements between the results are achieved for crack tips $D$ and $E$, which is due to their unique position, where the interaction effect of the adjacent crack tips is the smallest.

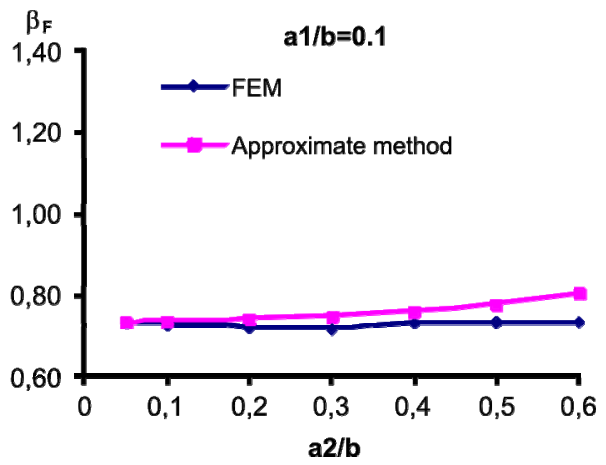

a)

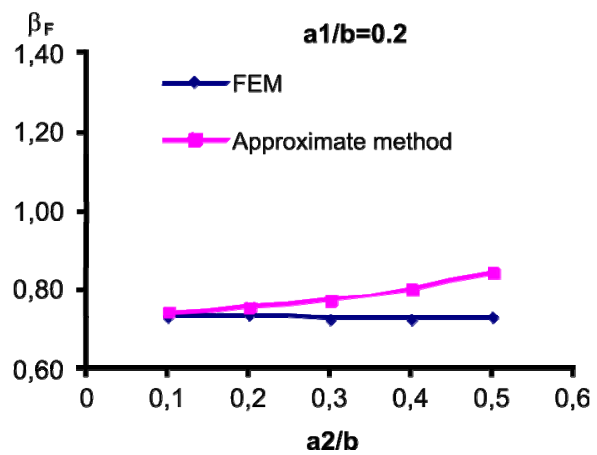

b)

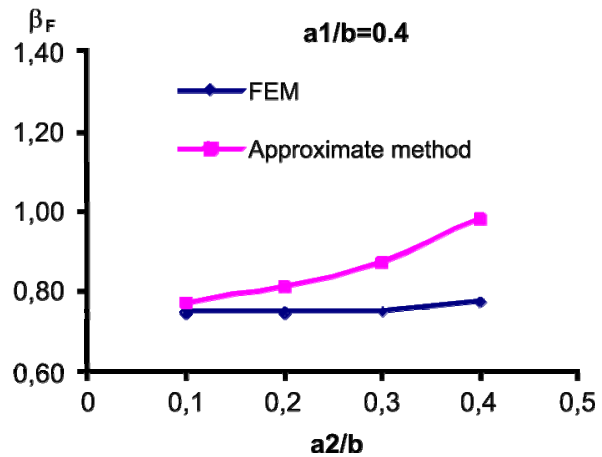

c)

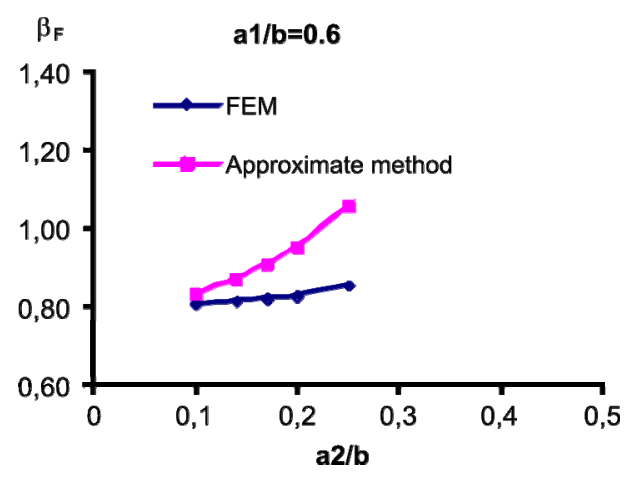

d)

Figure 6. Normalized SIFs for crack tips $C$ and $F, b=10 \mathrm{~mm}$

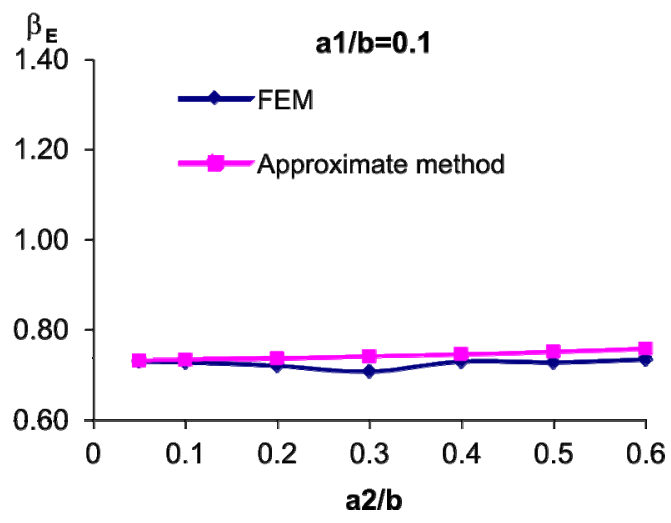

a)

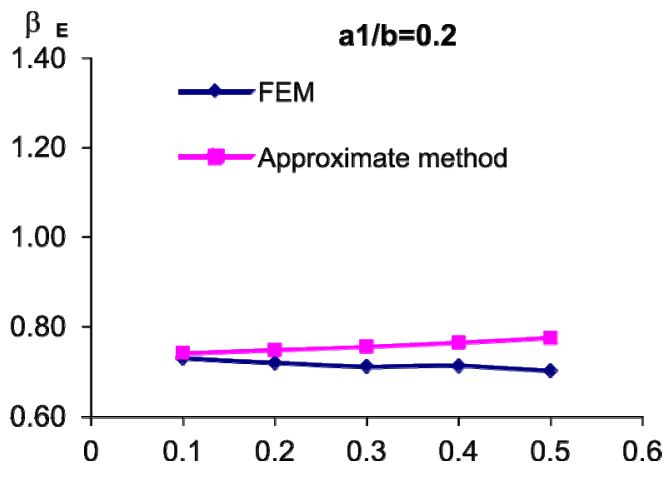

b)
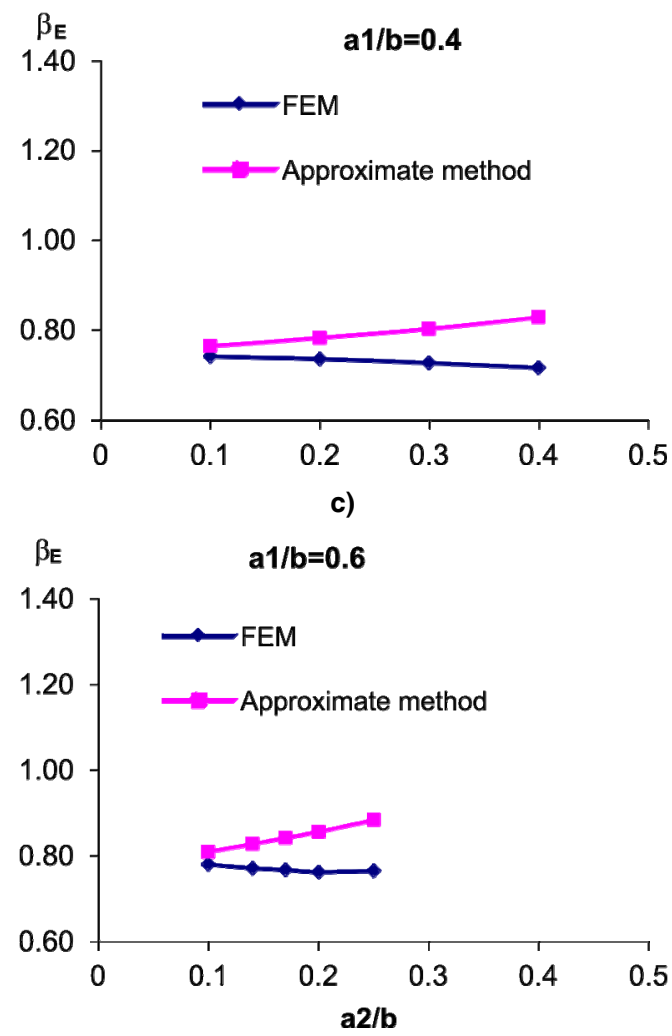

d)

Figure 7. Normalized SIFs for crack tips $D$ and $E, b=10 \mathrm{~mm}$

In the case when the $b=20$ [mm] (Figures 8 to 10), the maximum relative error is around $30 \%$ (fourth diagram in Figure 9). It should be noted that in this case, where $a 1 / b=0.6$, FEM based computer program could not obtain the SIFs solutions (could not create a mesh) for all calculation points (there is a gap in diagrams for $a 1 / b=0.6$ ). In other cases the relative error is lesser than 
in the cases where $b=10[\mathrm{~mm}]$, since the interaction effect is decreased due to larger distances between the cracks. For $b=20[\mathrm{~mm}]$, the best agreements between the results are also achieved for crack tips $D$ and $E$, which is due to their unique position, where the interaction effect of the adjacent crack tips is the smallest.

As it can be seen in the diagrams the agreements between the results are generally good. The approximate method gives larger values of SIFs.

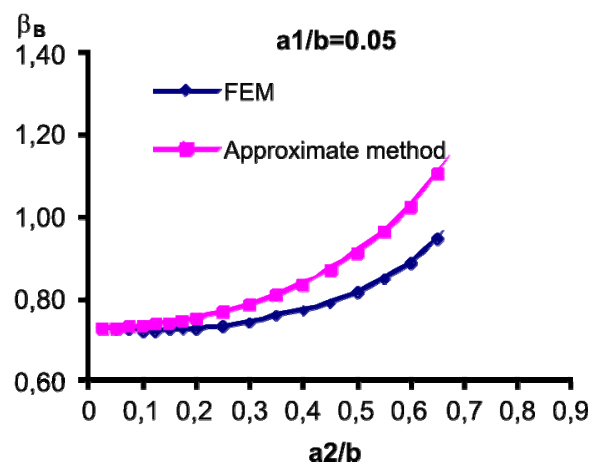

a)

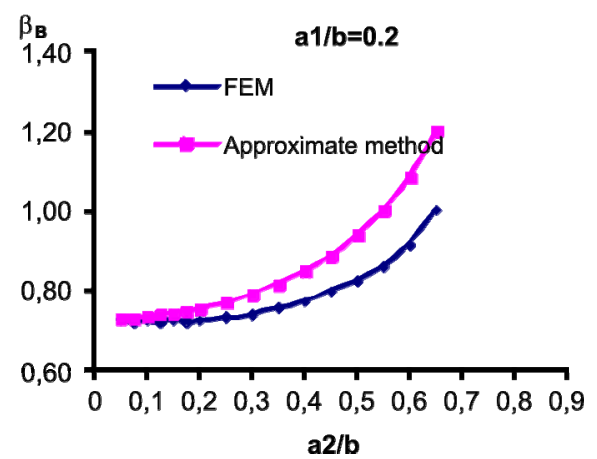

b)

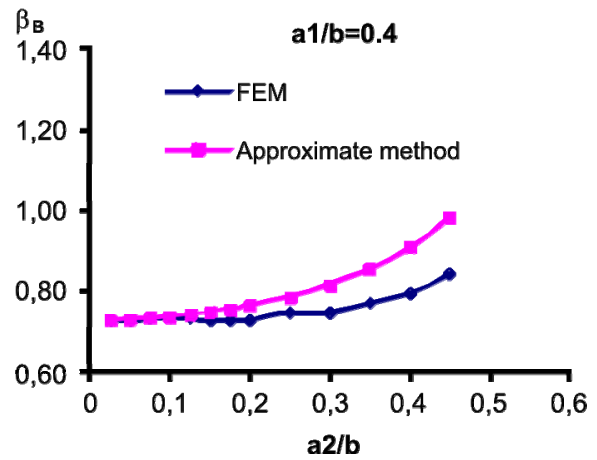

c)

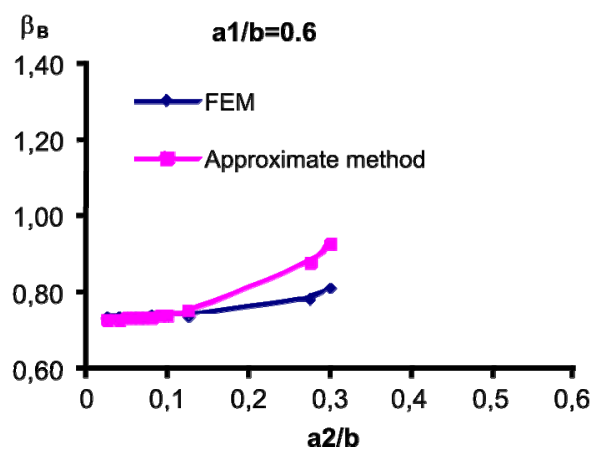

d)

Figure 8. Normalized SIFs for crack tips $A$ and $B, b=20 \mathrm{~mm}$

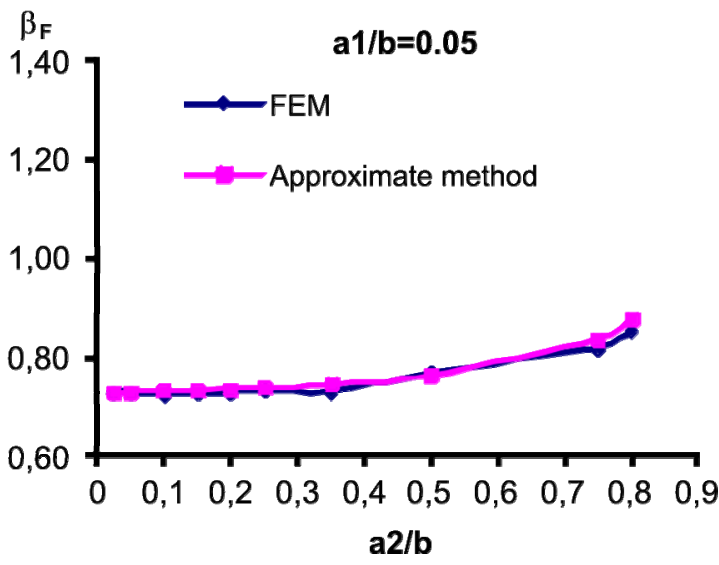

a)

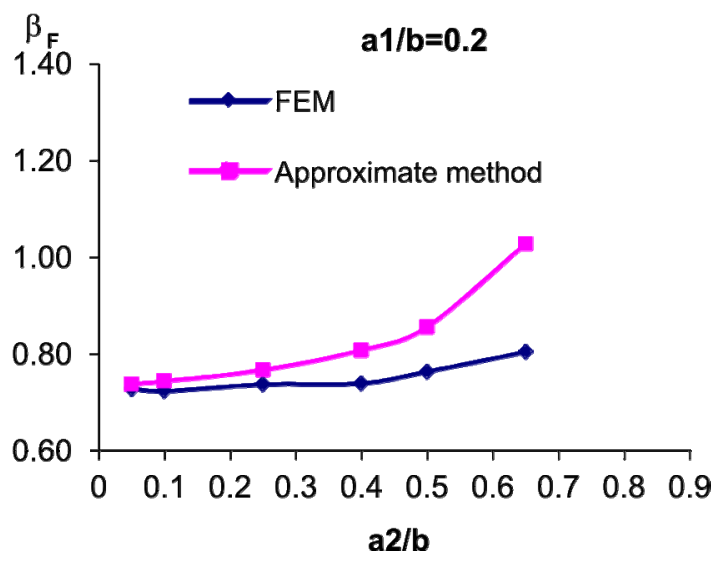

b)

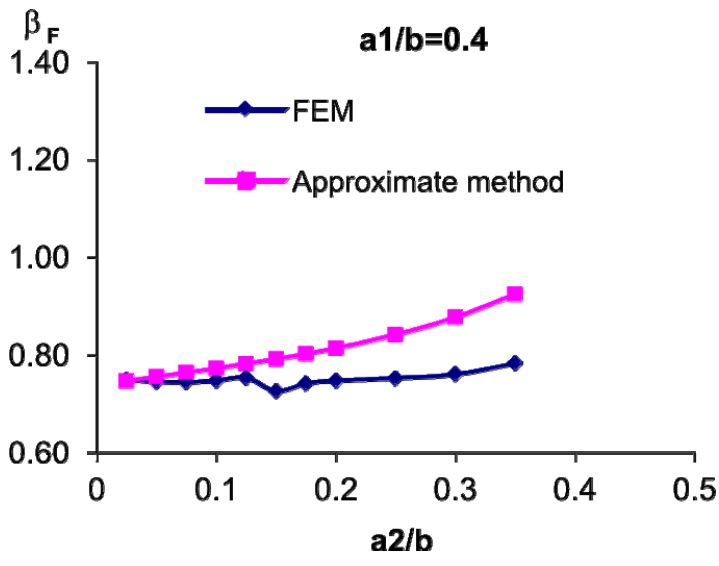

c)

$\beta_{F} \quad a 1 / b=0.6$

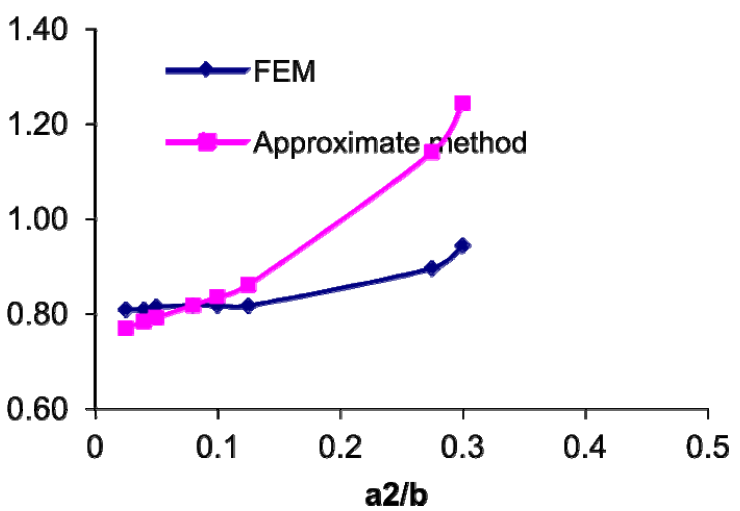

d)

Figure 9. Normalized SIFs for crack tips $C$ and F, $b=20 \mathrm{~mm}$ 


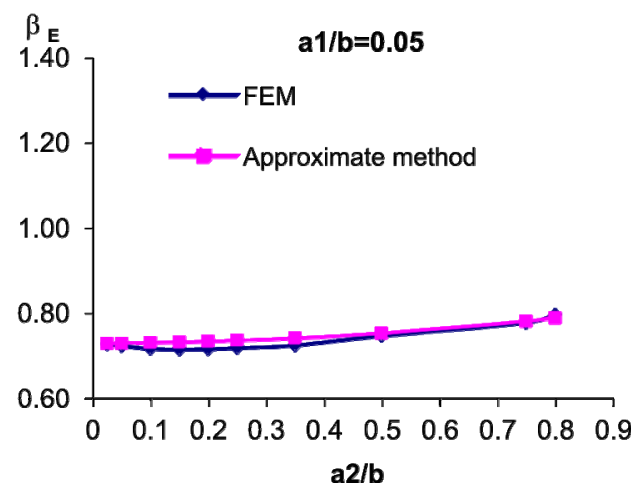

a)

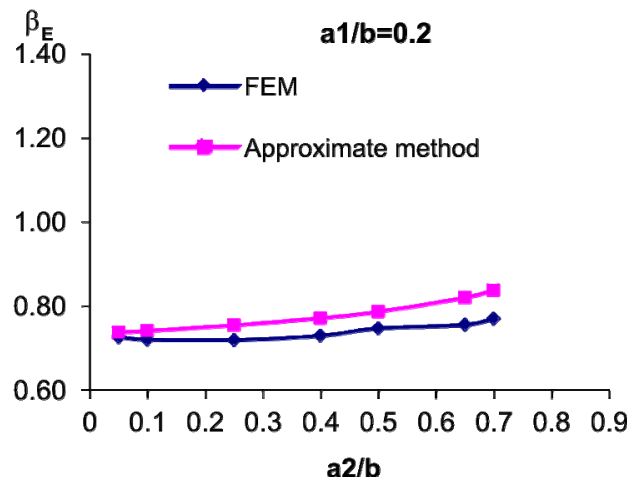

b)

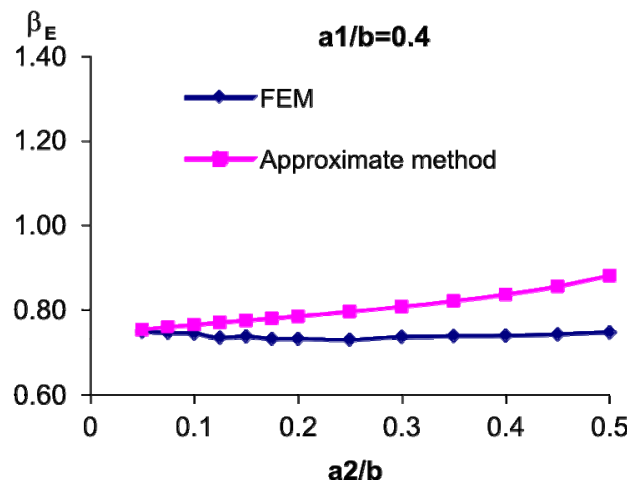

c)

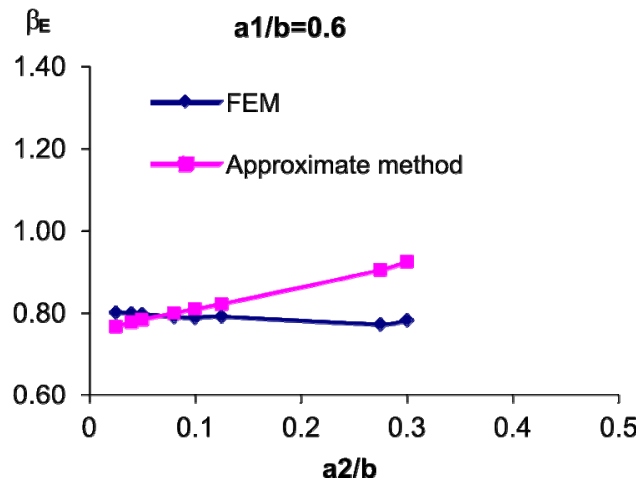

d)

Figure 10. Normalized SIFs for crack tips $D$ and $E, b=20 \mathrm{~mm}$

\section{CONCLUSION}

There are continuous investigations dealing with the problem of SIFs determination. The knowledge of this crucial parameter enables the prediction of crack growth rate and residual strength of damaged structure. Still, there is a lack of SIFs solutions for 3D configurations, especially in the case of multiple site damage. So, in this paper an approximate method was used for the estimation of mode $I$ stress intensity factors in case of three coplanar semi-elliptical cracks embedded in the three dimensional elastic body, subjected to remote uniaxial tensile loading. Then, for the verification purposes, the SIF solutions were obtained by using FEM based computer program. The FE model was created parametrically, so that SIFs solution could be calculated automatically for different sizes of all cracks.

The analysis of the results showed that in the case of small distant cracks, obtained solutions are in very good agreement, which makes them absolutely acceptable from an engineering point of view.

Also, the differences between the results increased with the increase of cracks sizes, regardless of distance between them. Here, it should be mentioned once more that influential coefficients were determined for 2D problem, which obviously affects the accuracy of calculated SIFs.

However, regardless of obvious shortcomings in the application of approximate method to this kind of configuration, this study also showed that for 3D structures with multiple cracks, with certain improvements, the use of the approximate method for SIFs assessments can be fully acknowledged.

\section{REFERENCES}

[1] Panasyuk, V.V., Andrejkiv, A.E. and Stadnik, M.M.: Three-dimensional static crack problems solution (a review), Eng Fract Mech, Vol. 14, No. 2, pp. 245-460, 1981.

[2] Collins W.D.: Some Coplanar Punch and Crack Problems in Three-Dimensional Elastostatics, in: Proceedings of the Royal Society of London, pp. 507-528, 1963, London, paper A274.

[3] Kachanov, M.: Elastic solids with many cracks: A simple method of analysis, Int J Solids Struct, Vol. 23, No. 1, pp. 23-43, 1987.

[4] Xiao, Z.M., Lim M.K. and Liew K.M.: Stress Intensity Factors for Two Coplanar Penny-shaped Cracks Under Uniaxial Tension, Int J Eng Sci, Vol. 32, No. 2, pp. 303-311, 1994.

[5] Lo, S.H. et al.: Integral equation approach for 3D multiple-crack problems, Eng Fract Mech, Vol. 72, No. 12, pp. 1830-1840, 2005.

[6] Hasib, M.A., Saimoto, A.: Analysis of Stress Distribution between Interacting Planar Cracks, Proceedings of the International Conference on Mechanical, Industrial and Energy Engineering, Khulna, Bangladesh, 2014.

[7] Schneider, K. D., Soares, C. C., and Al-Qureshi, H. A.: Cracking Propagation Prediction Methodology Applied for a Bulk Carrier, FME Transactions, Vol. 45, No. 3, pp 428-434, 2017.

[8] Petrašinović, N., Petrašinović, D., Rašuo B., Milković D.: Aircraft Duraluminum Wing Spar Fatigue Testing, FME Transactions, Vol. 45, No. 4, pp 531-536, 2017. 
[9] Moës, N., Gravouil, A., and Belytschko, T.: Nonplanar 3D crack growth by the extended finite element and level sets - Part I: Mechanical model, Int J Numer Meth Eng, Vol. 53, pp. 2549-2568, 2002.

[10] Tsang, D.K.L., Oyadiji, S.O. and Leung, A.Y.T.: Multiple penny-shaped cracks interaction in a finite bodyand their effect on stress intensity factor, Eng Fract Mech, Vol. 70, pp. 2199-2214, 2003.

[11] Kastratović, G.: Determination of stress intensity factor of supporting aero structures with multiple site damage, PhD thesis, Faculty of Mechanical Engineering, University of Belgrade, Belgrade, 2006.

[12] Kastratović, G., Grbović, A. and Vidanović, N.: Approximate method for stress intensity factors determination in case of multiple site damage, Appl Math Model, Vol. 39, No. 19, pp. 6050-6059, 2015.

[13] Online SIFs solutions (last accessed on April $7^{\text {th }}$ 2017):http://www.afgrow.net/applications/DTDHan dbook/Sections/page11_3.aspx

[14]ANSYS Mechanical APDL Documentation, ANSYS, Inc.

\section{АПРОКСИМАТИВНО ОДРЕБИВАНЕ ФАК- ТОРА ИНТЕНЗИТЕТА НАПОНА ЗА СЛУЧАЈ ВИШЕСТРУКИХ ПОВРШИНСКИХ ПРСЛИНА}

\author{
Г. Кастратовић, Н. Видановић, А. Грбовић, \\ Б. Рашуо
}

У овом раду коришћена је једноставна апроксимативна метода за процену фактора интензитета напона за мод $I$ тип оптерећења, и то у случају вишеструких површинских прслина у тродимензионалном еластичном телу, које је подвргнуто удаљеном једноосном оптерећењу. Наведена метода користи позната решења за 2Д или 3Д конфигурације које садрже само једну прслину и узима у обзир ефекат интеракције између истих. Ова метода, иначе заснована на принципу супер-позиције, конкретно је примењена на конфигурацији са три копланарне полуелиптичне прслине које су уметнуте у тродимензионално еластично тело, а које је подвргнуто удаљеном једноосном напону на затезање.

Све прслине се налазе у истој равни на истим растојањима, у средини тела, а примењени напон је управан на раван у којој прслине леже. За потребе верификације, фактори интензитета напона су одређении помоћу компјутерског програма базираног на методи коначних елемената.

Спроведена анализа показала је да је апроксимативна метода пре свега брз и ефикасан алат за процену фактора интензитета напона чак и у случају ЗД конфигурација са вишеструким прслинама. Поређење резултата показало је и значај прецизног израчунавања фактора интензитета напона, како би се омогућило боље разумевање и предвиђање ширења ЗД прслина. 